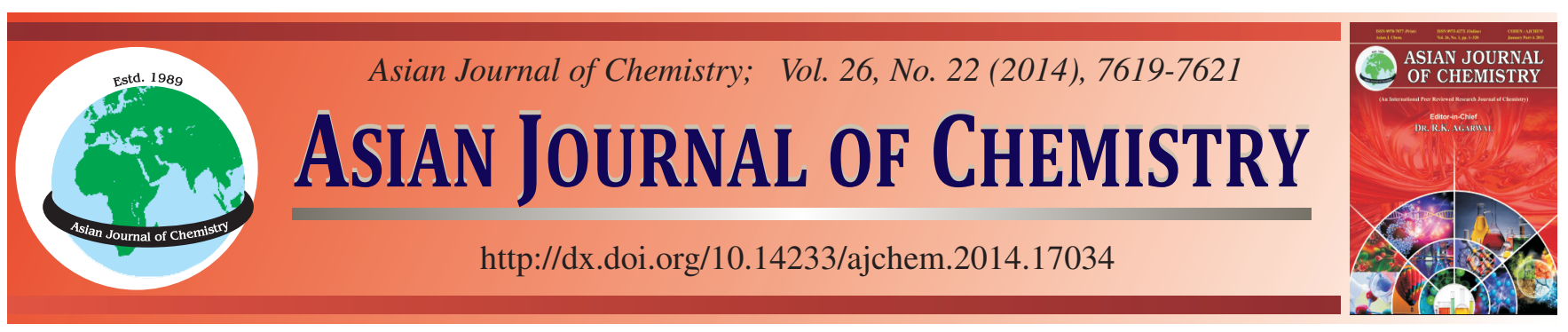

\title{
Synthesis of Key Intermediate of Phosphonosulfonates (BPH-652), 1-(3-Iodopropyl)-3-Phenoxy Benzene
}

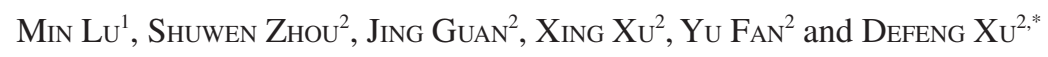

${ }^{1}$ Deparmtment of Chemical Engineering, Changzhou Institute of Engineering Technology, Changzhou 213164, Jiangsu Province, P.R. China ${ }^{2}$ School of Pharmaceutical and Life Sciences, Changzhou University, Changzhou 213164, Jiangsu Province, P.R. China

*Corresponding author: E-mail: markxu@cczu.edu.cn

Keywords: Phosphonosulfonates, BPH-652, 1-(3-Iodopropyl)-3-phenoxy benzene, Intermediate.

\section{INTRODUCTION}

1-(3-Iodopropyl)-3-phenoxy benzene (5) was widely used in biological and pharmaceutical fields ${ }^{1,2}$. It's a key intermediate of the preparation phosphonosulfonates such as (BPH-652) 1, developed by Bristol-Myers Squibb and advanced through phase I/II human clinical trials, potently inhibit S. aureus CrtM, as well as STX biosynthesis in the bacterium [3-5]. Many syntheses of 1-(3-iodopropyl)-3-phenoxy benzene (5) had been reported to prepare in the literatures ${ }^{3,6}$. Several methods used diethylmethanephosphate and methane-sulfonyl chloride and produced a large quantity of wastewater ${ }^{3,4,6}$. Some methods used lithium aluminium hydride which is a dangerous reagent in the chemical process. A safety and environmentally friendly technique needs to be used. This paper reports a convenient and efficient synthesis of 1-(3-iodopropyl)-3-phenoxy benzene (5) utilizing a kind of safety reduction reagent, sodium borohydride for reduction and potassium iodide and iodine for iodination to improve the yield.<smiles>[X]OS(=O)(=O)C(CCCc1cccc(Oc2ccccc2)c1)[V](=O)(=O)O[X]</smiles>

1 BPH-652

\section{EXPERIMENTAL}

Reagents and solvents were obtained from commercial suppliers and were used without further purification. All melting points were determined on a XT34 binocular microscope (Beijing Tech Instrument Co., China) and were not corrected. NMR spectra were obtained on a Mercuryplus 400 spectrometer $\left({ }^{1} \mathrm{H} \mathrm{NMR}\right.$ at $400 \mathrm{~Hz},{ }^{13} \mathrm{C} \mathrm{NMR}$ at $\left.100 \mathrm{~Hz}\right)$ in $\mathrm{CDCl}_{3}$ or DMSO- $d_{6}$ with tetramethylsilane as an internal standard; chemical shifts $(\delta)$ were reported in parts per million relative to tetramethylsilane. Chemical shifts were reported in ppm relative to the solvent resonance as the internal standard $\left(\mathrm{CDCl}_{3}, \delta=7.16 \mathrm{ppm}\right)$. Analytical TLC and column chromatography were performed on silica gel GF254 and silica gel H60, respectively.

(E)-3-(3-Phenoxyphenyl)-2-propenoic acid (3): A solution of 3-phenoxybenzaldehyde (50 g, $0.25 \mathrm{~mol})$, malonic acid $(52.4 \mathrm{~g}, 0.50 \mathrm{mmol})$ and piperidine $(5.0 \mathrm{~mL}, 50 \mathrm{mmol})$ in pyridine $(125 \mathrm{~mL})$ was stirred and heated at $90{ }^{\circ} \mathrm{C}$ for $24 \mathrm{~h}$. After being cooled to room temperature, the solution was poured into cold water $(1.5 \mathrm{~L})$. The $\mathrm{pH}$ of the aqueous mixture was adjusted to $\mathrm{pH} 2$ with concentrated hydrochloric acid. The solids which formed were collected by suction filtration, washed with water and recrystallized from ethanol to give (49.9 g, $82.5 \%$ in yield) of (E) -3-(3-phenoxyl phenyl)-2acrylic acid (3) as a white solid: m.p. $111.5-113.7{ }^{\circ} \mathrm{C}$. (lit. m.p. $\left.111-113{ }^{\circ} \mathrm{C}^{3}\right) .{ }^{1} \mathrm{H}$ NMR: $\left(400 \mathrm{~Hz}, \mathrm{CDCl}_{3}\right), \delta(\mathrm{ppm}), 7.73$ (d, $1 \mathrm{H}, J=15.9 \mathrm{~Hz}, \mathrm{ArCH}), 7.37-7.40$ (m, 3H, ArH), 7.27(d, 
$J=7.83,1 \mathrm{H}, \mathrm{ArH}), 7.01-7.17$ (m, 5H, ArH), 6.39 (d, 1H, $J=$ $\left.15.96 \mathrm{~Hz}, \mathrm{CHCO}_{2}\right)$

(E)-Methyl 3-(3-phenoxyphenyl)-2-propenoate (4): A solution of (E) -3-(3- phenoxyl phenyl) acrylic acid (3) (29 g, $0.12 \mathrm{~mol}), p$-toluene sulfonic acid $(7 \mathrm{~g}, 40 \mathrm{mmol})$, in absolute methanol (300 mL, $0.50 \mathrm{~mol})$ was refluxed with stirring for $18 \mathrm{~h}$. The methanol was removed in vacuo and the residue taken up in ethyl acetate $(250 \mathrm{~mL})$ and washed with a saturated aqueous sodium bicarbonate solution $(120 \mathrm{~mL} \times 2)$. The washes were back-extracted with ethyl acetate $(250 \mathrm{~mL} \times 2)$ and the combined extracts washed with brine, dried over anhydrous sodium sulfate and filtered. The filtrate was evaporated in vacuo to give (30.4 g, $93.6 \%$ in yield) (E)methyl 3-(3-phenoxyphenyl)-2-propenoate (4) as a yellow oil, which was used without further purification. ${ }^{1} \mathrm{H}$ NMR: (300 $\left.\mathrm{Hz}, \mathrm{CDCl}_{3}\right), \delta(\mathrm{ppm}), 7.64(\mathrm{~d}, J=15.2 \mathrm{~Hz}, 1 \mathrm{H}, \mathrm{ArCH}), 7.01-$ 7.38 (m, 9H, Ar), 6.37 (d, 1H, J = 15.2 Hz, $\left.\mathrm{CHCO}_{2}\right), 3.87$ (s, $\left.3 \mathrm{H}, \mathrm{CH}_{3}\right)$.

3-(3-phenoxyphenyl) propan-1-ol (6): A stirring solution of methyl 3-(3-phenoxyphenyl) propanoate (4) (13.4 g, 50 $\mathrm{mmol}$ ) in polyethylene glycol (PEG-400) $(250 \mathrm{~mL})$ was added in small batch sodium borohydride $(6 \mathrm{~g}, 160, \mathrm{mmol})$ at room temperature. The reaction mixture was allowed to stir at $65^{\circ} \mathrm{C}$ for another $10 \mathrm{~h}$ and then added dropwise $10 \%$ hydrochloric acid $(300 \mathrm{~mL})$ to no bubbles, extracted with ethyl acetate (200 $\mathrm{mL} \times 3$ ) and washed with saturated sodium chloride solution. The combined extracts were dried over anhydrous sodium sulphate and concentrated by evaporation of the solvent under reduced pressure to yield 3-(3-phenoxyphenyl) propan-1-ol (5) (8.6 g, 77.2\% in yield) as a colourless oil. ${ }^{1}$ H NMR: (300 $\mathrm{Hz}, \mathrm{CDCl}_{3}$ ), $\delta(\mathrm{ppm}), 7.09-7.35$ (m, 4H, ArH), 7.09-7.12 (m, $1 \mathrm{H}, \mathrm{ArH}), 7.06(\mathrm{~d}, 2 \mathrm{H}, \mathrm{ArH}), 6.86(\mathrm{~d}, 1 \mathrm{H}, J=1.5 \mathrm{~Hz}, \mathrm{ArH})$, $6.83(\mathrm{~m}, 2 \mathrm{H}, \mathrm{ArH}), 3.66\left(\mathrm{t}, J=6.42 \mathrm{~Hz}, \mathrm{CH}_{2}\right), 2.67(\mathrm{t}, 2 \mathrm{H}, J=$ $\left.7.74 \mathrm{~Hz}, \mathrm{CH}_{2}\right), 1.84-1.89\left(\mathrm{~m}, 2 \mathrm{H}, \mathrm{CH}_{2}\right), 1.47(\mathrm{~s}, 1 \mathrm{H}, \mathrm{OH}),{ }^{13} \mathrm{C}$ NMR: $\left(100 \mathrm{~Hz}, \mathrm{CDCl}_{3}\right), \delta(\mathrm{ppm}), 156.28,142.91,128.69$, $128.60,122.35,122.12,117.89,117.81,115.32,61.19,33.02$, 30.93 .

1-(3-Iodopropyl)-3-phenoxybenzene (6): Mixtures of phenyl phosphine $(13.1 \mathrm{~g}, 50 \mathrm{mmol})$, iodine $(12.8 \mathrm{~g}, 50 \mathrm{mmol})$, potassium iodide $(0.8 \mathrm{~g}, 5 \mathrm{mmol})$ and dichloromethane $(250$ $\mathrm{mL}$ ) were stirred at room temperature under nitrogen atmosphere for $20 \mathrm{~min}$. To the reaction solution was added imidazole $(6.82 \mathrm{~g}, 100 \mathrm{mmol})$ and continued to stirring for another 20 min and then added the solution of 3-(3-phenoxy- phenyl) propan-1-ol (5) (7.6 g, $33.3 \mathrm{mmol})$ and dichloromethane $(50 \mathrm{~mL})$. The reaction mixtures were stirred at room temperature for $4 \mathrm{~h}$, after reaction, added saturated brine water, extracted with dichloromethane $(100 \mathrm{~mL} \times 3)$. The combined organic extracts were dried (anhyd. $\mathrm{MgSO}_{4}$ ) and concentrated under reduced pressure. The resulting residue was purified by flash chromatography (95:5 petroleum ether: ethyl acetate) to afford 1-(3-iodopropyl)-3-phenoxy benzene (6) (10.5 g, $93.2 \%$ in yield) as a colourless oil. ${ }^{1} \mathrm{H}$ NMR: $\left(300 \mathrm{~Hz}, \mathrm{CDCl}_{3}\right)$, $\delta(\mathrm{ppm}), 7.22-7.27(\mathrm{~m}, 3 \mathrm{H}, \mathrm{ArH}), 7.12$ (t, $1 \mathrm{H}, \mathrm{ArH}), 6.95-$ $7.01(\mathrm{~m}, 3 \mathrm{H}, \mathrm{ArH}), 6.83(\mathrm{~d}, 2 \mathrm{H}, J=1.62 \mathrm{~Hz}, \mathrm{ArH}), 3.17(\mathrm{t}, J=$ $\left.6.82 \mathrm{~Hz}, \mathrm{CH}_{2}\right), 2.70\left(\mathrm{t}, 2 \mathrm{H}, J=7.32 \mathrm{~Hz}, \mathrm{CH}_{2}\right), 2.06-2.15(\mathrm{~m}$, $\left.2 \mathrm{H}, \mathrm{CH}_{2}\right)$; $\mathrm{C}^{1} \mathrm{NMR}:\left(100 \mathrm{~Hz}, \mathrm{CDCl}_{3}\right), \delta(\mathrm{ppm}), 142.49,129.93$, 129.57, 123.38, 118.76, 36.10, 34.65, 6.14.

\section{RESULTS AND DISCUSSION}

Recently studies the phosphonosulfonates and a key intermediate 3-(3-phenoxyphenyl) propan-1-ol (4) showed that the reduction of (E)-methyl 3-(3-phenoxyphenyl)-2- propenoate (3) using sodium borohydride in the present of PEG-400 affords 3-(3-phenoxy phenyl)propan-1-ol (4) in good yields. The optimization of the synthetic conditions for 1-(3-iodopropyl)-3-phenoxy benzene (2) and 1-(3-iodopropyl)-3phenoxy benzene (5) were examined.

The condensation of substituted benzaldehyde and malonic acids in the presence of pyridine and piperidine gave the expected cinnamic acids in good yields according to the literature. The yield of condensation of 3-phenoxybenzaldehyde and malonic acid was $82.5 \%$. It was found that the $p$ toluene sulfonic acid was a good esterification catalytic to yield (E)-methyl 3-(3-phenoxyphenyl)-2-propenoate (3). The yield of esterification was $93.6 \%$.

Lithium aluminium hydride is an excellent reagent for the reduction and hydrolysis of certain polar groups, but it was a highly flammable solid and may ignite in moist or heated air. It is a dangerous reagent in the process for reduction. In the paper, the relative safety of reductive reagent, sodium borohydride, was be used. The yield of reduction was $77.2 \%$.

Iodination of 3-(3-phenoxy phenyl) propan-1-ol using iodine in the present of KI, KI can improve the yield of iodination under the imidazole as catalyst, the yield of iodination is $93.2 \%$ (Scheme-I).

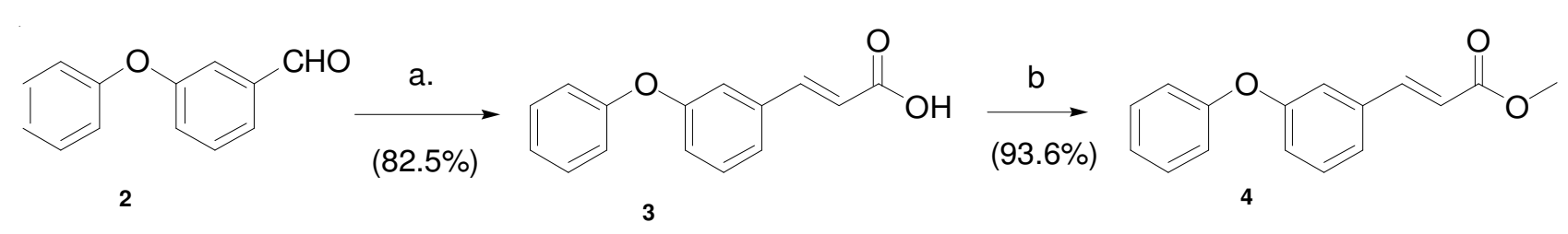
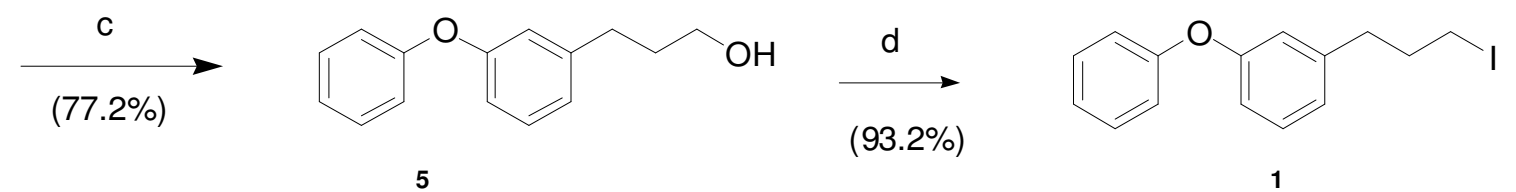

Scheme-I: Reagents (a) malonic acid, pyridine, piperidine (b) methanol, p-toluene sulfonic acid (c) $\mathrm{NaBH}_{4}, \mathrm{PED}-400$ (d) $\mathrm{l}_{2}, \mathrm{KI}, \mathrm{P}(\mathrm{Ph})_{3}$, imidazole 


\section{ACKNOWLEDGEMENTS}

This project is supported by the Introduction Talent Fund of Changzhou University.

\section{REFERENCES}

1. Y.C. Song, C.I. Liu, F.Y. Lin, J.H. No, M. Hensler, Y.L. Liu, W.Y. Jeng, J. Low, G.Y. Liu, V. Nizet, A.H.J. Wang and E. Oldfield, J. Med. Chem., 52, 3869 (2009).
2. D.R. Magnin, S.A. Biller, J.J.K. Dickson, R.M. Lawrence and R.B. Sulsky, US Patent, 5,470,845 (1995).

3. Y. Song, F.-Y. Lin, F. Yin, M. Hensler, C.A. Rodrígues Poveda, D. Mukkamala, R. Cao, H. Wang, C.T. Morita, D. González Pacanowska, V. Nizet and E. Oldfield, J. Med. Chem., 52, 976 (2009).

4. T.T.W. Cheng and M.A. Poss, US 5618964 (A) (1997).

5. E. Oldfield and Y.C. Song, PCT Int. Appl., WO 2010123599 A2 20101028 (2010)

6. E. Oldfield and Y.C. Song, US Appl., 2012022024 (A1) (2012). 